Journal of Awareness

Cilt / Volume 5, Say1 / Issue 2, 2020, pp. 147-158

E - ISSN: 2149-6544

URL: https://www.ratingacademy.com.tr/ojs/index.php/joa

DOİ: https://doi.org/10.26809/joa.5.012

Araştırma Makalesi / Research Article

\title{
ECONOMIC ASPECTS OF THE CITY OF PRIZREN XIII - XV CENTURY
}

\author{
Bedri MUHADRI* \\ * Dr. Sc., Professor Associate, Institution of History "Ali Hadri", \\ Head of Department of the Medieval History, Prishtina, KOSOVO \\ e-mail: bmuhadri@hotmail.com \\ ORCID: https://orcid.org/0000-0001-7583-653X
}

Received: 29 March 2020; Accepted: 4 May 2020

\begin{abstract}
Prizren during the c. XIII-XV was a developed economic center. This development was made possible thanks to several factors: Prizren was an important center of medieval roads for the region; In Prizren, the Ragusan consulate (1332) was opened as a requirement for the development of more successful business activities. Thus Prizren in the 13th-15th century was a city of traders and trade exchanges. Traders in defense of their own interests created their own associations, such as shoemakers in Prizren. Commercial products came from the most developed countries, such as Venice, Naples, Ragusa, Constantinople etc. Traders operating in Prizren, besides importing economic products, they also exported numerous products such as cereals, barley, fern, silk, honey, etc; As well as mining products such as: lead, zinc, and gold-plated silver, known as silver (galam). The sources speak for a large number of traders, as well as for large monetary circulation through the form of lending and debiting. Among many foreign merchants, there were also distinguished prizrenas merchants, who either come as debtors or creditors, where Bogdan Chirisma.

In the 13th-15th centuries, besides trade developments, in Prizren and the surrounding area, agricultural and livestock activities have also been successfully developed. This development is evidenced by numerous sources such as: The Monastery of St Archangel 1348, which included 93 villages; Deçan Monastery Charter 1335. From the development of agriculture, the sources speak of successful aspects of viticulture, grain, barley, flax. The sources also speak for beekeeping, silkworm, etc.

Keywords: Prizren, "Via de Zenta", Monastery of Saints Mihail and Gabriel in Prizren, Hilandar Monastery, States Archives of Dubrovnik, Honey, Wax, Silk, Mining, Nicho de Baraba, Marthol de Sorgo, Bogdan Chirisma de Prisreno, Grand Council of Ragusa, Nemanjid Uroshin V, Marin de Bona, Giovani de Gondola and Giue de Cerva Ottomans, Pristina, Diplom of Saints Micheal and Gabriel (1348), Trepca, Novoberdo, Manastery of Decani, Paulus de Martinusso, Assembly of Raguziana.
\end{abstract}




\section{ECONOMIC ACTIVITIES IN THE CITY OF PRIZREN AND ITS SURROUNDING, DURING THE XIII - XV CENTURY.}

Researches in the economic fiels of many scholars show that Prizren during the XIII $\mathrm{XV}$ century was among the most developed economic and trading areas in the Balkans. The development of economic relations influenced mamy factors.Prizren was an important center of the medieval streets, especially the road of Zetës "Via de Zente" that connected Prizren with Adriatic and that had its branches in the region that connected the places around. ${ }^{1}$

For this period (shek XIII-XV) of change, from the early Middle Ages there are sources in which a picture can be formed of the level of development of economic activities in Prizren.

The monastery card in the holy archangel brings important records to Prizren and the surrounding economy. In the complexof the Archangel Monastery are included 93 villages. The main one's were the villages of Prizren region that were in the province ( Zhupa qualified, according to Slavic documents) of Opojës, Gorës, Patkovës (the province between Prizren and Gjakova).In these family households were developed all the professions ranging from livestock, farming,craftsmanship, etc. ${ }^{2}$

Agriculture entered the ranks of the most developed medieval branches in Kosovo. The Archbishop of Skopje in 1330 writes that in Rashkë (and in Kosov becaise it entered its territorial framework), domimated legal happiness, the country was rich in grain, wine, fat, meats, fertile ground, where gravitating rich water resources with all kinds of animals...", ${ }^{3}$ Anonymous Venetian(1359), traveling from Prizren in the direction of Skopje passes through rich fields and completely sown. ${ }^{4}$ Gjakomo Soranco (1575) states in his own terms that "Kosovo has fields and fertile land, as well as a great interest of farmers to produce. ${ }^{5}$

Vineyard as an economic branch was widespread im the district of Prizren, ${ }^{6}$ even in villages around Deçan and Peja. ${ }^{7}$

The progress of this economic branch seemed to have begun by the end of the XIII century, also seen from the donation of Dragutin to the Hilandar Monastery, among which were donated villages with vineyards around Prizren, such as the village of Bilush, and the curch of St.Demetrius along with vineyards. ${ }^{8}$

Even Ottoman sources of the XV. Century provide information that vineyards were highly developed. Vineyards in most cases were considered as a base, meaning the brought large incomes. ${ }^{9}$ According to the sources of that time, especially by the monies'statues, we learn that hrain, wheat, barley, rey, oats and mill are cultivated in the territory of Kosovo.Important facts include the Raguzane sources of the Historical Archives of Dubrovnik such as: Testamenta Notaria; Diversa Notariae, Diversa Cancellriae etc., where are presented reports of economic activities of export and import of agricultural products.

Ragusan sources testify to the export of grain from Kosovo to Ragusa in the 20th century XIV. The Ragusa merchant Sune Orse de Bodaça (1322-1363), whoh we met in 1332 in Prizren, in 1345, carried in Ragusa, grain of about 282 starias. $^{10}$

Another agriculture product that was mentioned in Prizren and the surrounding area was freedom. The villagers of the district of Prizren were obliged to hand over to the Monastery of Saints Mihail and Gabriel 30 meters toed flax, as well as a considerable amount of silk. ${ }^{11}$

Orchard as an economic branch was developed in the villages of the district of Prizren at the beginning of the XII century. It was developed throughout Kosovo. In the documents there are mentioned the sweet, red and small apple's, while for pears the information they described as early pears, while for cherries as idle. ${ }^{12}$ 
Among the widespread occupations of Prizren's population with the surroundings in the medieval period was beekeeping. From this actiity honey and wax were very much produced in the Middle Age.In 1331, beekeeping of King Stefan Deçanski was mentioned in Zhur near Prizren, later transmittes to a meadow near Dobrushë. Beekeeping in question belonged to the Bishop of Prizren who was donated by the King to him and the wax house in Prizren (which had beenraised by the Kotorrasit), ${ }^{13}$ together with the right to monopoly for wax melting. ${ }^{14}$

In Prizren there was the main halibutage for sale with an income of 3333 acres per year, whereas in the territory of this nahije there are also honey-related taxes. ${ }^{15}$ Although there is not much information that directly refers to the import of wax, from information given by researcher Jahja Drançolli, we learn thag in the first half of the 20th century XIV, Raguzan merchant Gui de Georgie from Prizren imported, among other things, wax and honey. ${ }^{16}$ Important information regarding the beekeeping we encounter Ottoman defters, such as that of 1455, and that of Vuçitërna and Prizren.Honey production in the area of Kosovo at the time of Ottoman power was under the supervision of the government. Interestingly, due to the importance of honey, the Ottomans prohibit its export abroad, such as gold and silver. It was used for candles and cakes, replacing sugar, as well as for other industrial needs. ${ }^{17}$

Since the first half of the XIV century cultivation of silkworm was a particular feature of some villages in the suburbs of Prizren.The lower families of the Lower Pult cultivated the silkworm and most likely they produced silk fabrics for their own needs and were obliged to give the monasteries every year a certain amount of maize. ${ }^{18}$ For this purpose, Deçans 1335 warrant is issued. According to its provision, King Stefan Deçanski assigned the two monks of Deçan: "Zaharia and Mihail in Pult, in Nikiti and let them give it to the curch every year, Zaharia 4 thousand, while Mihail 2 thousand. ${ }^{19}$ Also in the Charter of Emperor Dusan for the Monastery of Saints Mihail and Gabriel is spoken of some "Downhill" people who were assigned to give the silk the church a hundred thousand worms or 100 perpetutes. ${ }^{20}$.At the same time, it is mentioned in a neighborhood village Ivan the Shepherd of Prizren. ${ }^{21}$

The abovementioned sources clearly say that in the area of Prizren and beyond in the Dukagjini plain, was cultivated silkworm and silk and silk fabrics were also prosuced.

Secure announcements for the production of Silk fabrics provide the documents of the Dubrovnik Archives, which indicate that Prizren in the 19th century XIV was the center of production of fine Silk fabrics. ${ }^{22}$ It is also know with certainty that during the 19th century XIV Ragusans traded with Prizren silk.This is evidenced first of allby the testament of Andrea Poborich, who probably lived in Prizren for some time. ${ }^{23}$ When mentioning one of the goods that he leaves in his home, except the skins, waxes and various Italian fabrics, he also mentions silk. $^{24}$ Therefore, it can be assumed, writes Jahja Drançolli, that Andrew exported the Albanian fabrics to Prizren, while from Prizren he exported raw silk to Venice.

The silk of the Prizren region was the required item and still represented gpods of significant value. For this is shown a document that shows that King Dusan restored in 1334 his debts to traders, two Venetians and a Florentine, except im cash and silver, and with silk blazer. $^{25}$

In the first half of the 20th century XIV a major role in the fabric trade was Giue M.de Georgio, who once lived in Prizren. ${ }^{26}$ This merchant in Prizren sold various Italian fabrics, while from Prizren imported and sold raw silk to Venice. Trading and exporting silk was very actively taken (1348-1352) by Venetian merchants Nicoletto Contarini, then Ragusan merchants Petrus de Mence and brothers Micheal and Marinus de Bona. ${ }^{27}$

For the export of silk from Prizren through Ragusan merchants in Venice, a document is fully addressed on 26 September 1366. The document in question states that Andrea de Sorgo 
had received silk from Bzicho Bogdsaevich of Prizren "libri 28 onc. 9 sirici extrati". ${ }^{28}$ For lack of resources, the issue of silk price can not be fully illumimated, but according to the account, the price of a silk thread of royalty amounted to three or four perpetuals, while the price of a silk blazer, based on the information of the Emperor Dushan's charter of the Monastery of Saints Mihail and Gabriel in Prizren was a perpetual in production. ${ }^{29}$

In addition to the developed economic activity in the field of agriculture, Prizren woth its surrounding durong XI-XV century was also a center of developed handocrafts. Numerous sources of scientific evidence proves the high level of handicrafts development in Kosovo since ancient times. ${ }^{30}$

The first notes on the development of handicrafts during the medieval period are found in the Emperor Dusan's crisobula, with which he established the monastery of Saints Mihail and Gabriel in Prizren. According to this document, a person known as Rojko as master and along with six regular shoemakers is presented in Prizren. ${ }^{31}$

In the chaplains of the Saint Mihail and Gabriel are also memtioned the names of some craftsmen who worked in the maintenance of the church of St.Spase and operating in the city as well as Divsho Rado Kovaçi, Llesh Poçaris son's, Leshko jeweler of Dobroslas jeweler and the son's of the jeweler Zavediç. ${ }^{32}$ According to the Ragusan information, im the XIV century and beyond, even to this day, various types of households and personal fabrics have been made of silk, as well as other handicrafts for everyday necessities, such as tablecloths, curtains, bags and so on. ${ }^{33}$ Prizren's goldsmiths also produced various beatiful objects such as earrings, bracelets, rings, necklaces and other items of gold, silvrr and bridal. ${ }^{34}$

The presence of the Ragusan craftsmen in Kosovo influenced the development of the craft of cold weapons in this territory, including Knives, swords, and so on. As well as firearms where the most commonly used.

This finding is argued by researcher Jahja Drançolli through the contract of Prince Lazar and Ragusa Milisa Radosavlkevic (13.IX.1386). The last ome commited to work for the ballist prince for a one-year term. When this information is taken into account, it concludes the researcher speaking, and we can also advance the view thinking that gunfire was used in the Battle of Kosovo. ${ }^{35}$

The Prizren monastery's map shows that in Prizren and around the area were practiced these craftsmen: wreaths, tinwork, leatherworkers, shoemakers etc.

One of the most important economic branches that has had significant development in Kosovo since ancient times, especially during the Middle Ages, is mining. ${ }^{36}$ According to our well-known scholar Skënder Rizaj, Kosovo's miming is divided into several regions such as the mining of NovoBërdë province, Kopaonik mining, Prizren and Dukagjini mines. In these minings mainly there are taken out lead, zinc, and silver, mixed with gold (silver galam). Foreign writers and contemporaries praise the Medieval Serbian state for its rich and glorius gems. Byzantine Emperor Kristobul in 1453 he writes that in the "Serbian states (as well as Kosovo) wherever it is excavated, there are rich layers of gold and silver, which are richerthan the Indian oaks. ${ }^{37}$ Recently, but even earlier, in the history of science there has been controversy about the technique of pure metal profit. The researcher V. Vinaver points out that the Raguans, brought in Kosovo the noble metal washung machine, cleansing the minerals. ${ }^{38}$ The opinion of the scholar in question, writes Jahja Drançolli can not stand the scientific truth, since from the information it is possessed, it can be concluded that the purification of silve and gold in Kosovo is a contiuation of the past. In recognition of the technique in question, there are also information on the Charter of Establishment of the Monastery of Saints Mihail and Gabriel of Prizren.It mentioned the goldsmiths of Prizren. ${ }^{39}$ This shows that Bistrica of Prizren brought 
gold and the mountains of Bistrica of Prizren does have gold. ${ }^{40}$ Also, some silver cleaning tolls "affinata argenti" are rumored in 1418 in Pristina. ${ }^{41}$

The high level of mining development in Kosovo is well knwn in other centers such as Trepça, Novk Bërda, and Janjeva and so on. ${ }^{42}$ The devoted traveler of the XIV century, Frenchman Broard, in his own writing Directotium ad Passagium ultra mare (1332) it also speaks about silver (silver mixed with gold). ${ }^{43}$

The gold of Kosovo has been sold in Ragusa and other European centers, not only as a mixture of siver but also as pure gold. In 1371 the Ragusa merchant Luca de Bona bought a Prizrena's dealer for about 18 gold rings. ${ }^{44}$

\section{PRIZREN CITY OF TRADERS IN THE XIII-XV CENTURY}

Prizren was one of the most important shopping centres in Kosovo during the 13th-15th century. Because of its position, it has attracted the attention of the Ragusan merchants. The activity of the consulate of Ragusa ${ }^{45}$ and the existence of the great colony of Ragusan merchants in Prizren has resulted in the development of trade ralations. Since these relationships imply greater capital participation, mutual credit was indispensable.

An important role in the development of trade has been the trade associations presented in the form of colleges (colleqantia) or associations (societas). Commercial associations were established in order to unite the financial means to reduce the risk of travel, so that it could be gained more easily. These associations counted several people and it seems one of the representatives of the association was in Ragusa, while others operated in colonies in the territory of Kosovo. ${ }^{46}$ Any person authorized in this association had certain obligations. The fundamental principles of commercial associations in Ragusa have been established since 1272, when the Raguzan Statute was drafted. ${ }^{47}$

Representatives of a Ragusan trade association in Kosovo meet for the first time in the first half of the 20th century XVI, exactly in 1330. Nicho de Baraba (1319-1330) mentions in his testament a quantity of goods owned by him in Prizren. ${ }^{48}$ Nicho de Baraba along with Marthol de Sorgo led an associations. These were trading with wax and various textile materials. Meanwhile, according to the note of 1335 , one of the representatives of the associations' enganged to carry the skins from Prizren to Ragusa. ${ }^{49}$

The most important Prizren dealers to whom they could borrow were the noble families from Ragusa, who live or worked in Ragusa, often in Prizren.

According to the documents, Kosovar dealers appear from the end of the XIII century: first, in 1298, we encounter prizrenas dealer Drasisclaus Rubini as the debtor (460 perp) of Ragusan Fuscho de Lucari. ${ }^{50}$ A year later on 1299, we again meet a prizewinning merchant as a debtor (400 perp) of Raguzani Laurencio de Savima.It was mentioned for the dealer Bogdan Rodoslav. ${ }^{51}$ In 1330, as a debtor we meet Krabeç of Prizren. He took 200 credits from the Ragusan Alegrebo. ${ }^{52}$ Meanwhile, in 1301, the prizrenas dealer Rade Dobrelovic assumed the obligation on the basis of the property owned by Marco Lucari de Fuschs to give17 perp within two months. ${ }^{53}$

From these figures it can be concluded that the number of prizrenas traders was considerable. ${ }^{54}$ During the aforementioned years prizrenas traders were credited by many noble families such as Marinus and Paulus (de Vitagna) de Baraba, as well as other Ragusan merchants (creditors), especially by Marinus Junii de Gozze, Luca de Bona, Luca de Dobro, V. Saranouich, Bosse Goranouich, Pruoslao Gorenouich and others. ${ }^{55}$ Out of all these creditors the one family that was the most outstanding or majestic was the family De Barbara (de Vitagna). The two representatives of this family, Marinus and Paulus de Barbara (de Vitagna), during the 
fifties and sixties of the nineteenth century. XIV honored 67 prizrenas merchants, while the total amount of the loan was 30,669 ducats. ${ }^{56}$ Marinus de Barbara began honoring prizrenas merchants from 1355 to 1363 . During this period, from their bank, they credited them with an amount of 8224 or 16,448 perper. ${ }^{57}$ Even Paulus (de Vitanga) de Barbara during 1364-1369 credits or entrusted 38 prizrenas merchants. During these years he has deposited a total of $22,170.5$ ducats, or 44.341 perp. ${ }^{58}$ From the total turnover these two participated in an amount of 30,669 ducats from the total amount of 33,980.5 ducats. ${ }^{59}$ Of the prizrenas merchants who were credited by the most famous Ragusan merchants was Bogdan Chirisma de Prisreno. XIV we find him continuous in Ragusa papers, especially in the Debita Notaria books. The prizrenas dealer Bogdan Chirisma is mentioned for the first time in 1359 when he received credit from the Raguzan merchant Vesco Saranovic in a total of 29 ducats with a three month return. ${ }^{60}$ In the same year at the beginning of September he appeared with a loan in the amount of $110 .{ }^{61}$ Next year we meet Chirismus three times in Ragusa. ${ }^{62}$ When it comes to the appearance of Chirism as a borrower in Ragusa, he borrowed from 1359 to 1369 an amount of 19,832 ducats. ${ }^{63}$ Marinus and Palus de Barbara are his creditors. At the time when King Vukashin ruled Prizren, Chirisma was elected his protovest. ${ }^{64}$

During the mentioned years prizrenas traders are found in Ragusa not only as debtors, but also as merchants with different goods. This example is found in merchants trading in cloths. Meanwhile, as traders we have "de Tudisio comoratntibusn in Presreno...debean sdixcere ...et...Georgio Marchauich,... Bogodasseuich, cgnato suo, et Nicole fratri Teudori de Presreno, who were known for clothe trade. ${ }^{65}$

Numerous commercial reports between Ragusa and Prizren, which we find in the Ragusa documents summarized in Acta Cancellariae Et Notariae Annorum 1278-1301, testify the high level of trade-economic exchange. For example, In 1299 Ragusa Vladimir Grupsi bought for twenty perp the Deana robin from Prizren. ${ }^{66}$ In 1302 in Prizren, we encounter Raguzan generous Georgiu de Spavaldo. ${ }^{67}$ The business relationship with Prizren has had a generous Raguzan with a native origin Thomas Pauli de Thoma, who owned a house in Prizren. ${ }^{68}$

Brothers Marinus and Michael de Bona, according to the document issued in Nerodime on September 10, 1340, Stefan Dusan was granted the right from 1335-1342 to keep the Prizren and Zeta customs (li merxcadi di At the end of the document we come across the note written in Latin: "...li mercadi di uno logo, che a nome Nerodimle Çenta (Zenta) et lo mercato de Preseren septe anni..." ${ }^{69}$ Meanwhile, from 1342-1348, Prizren's customs were kept by their youngest brother Johannes. ${ }^{70}$ Customers of customs in Prizren and Novobërdë in 1349, according to the statute of Stefan Dushan, are the brothers Marcus and Matheo Basellio. ${ }^{71}$

Regarding the importance of Prizren as a shopping mall we have information in the decision of the Little Raguzan Council. By the decision dated 14. V. 348 we learn that Ragusan merchants Climento de Dersie, Syme Stephani, Ractio de Sumagna; mercatoribus ad Narentum, in Drina, in Bresco et in Pristren..., and Maroe de Benessa, except with Bosnia's cities, also traded with Prizren. ${ }^{72}$

Development of trade relations between Prizren and foreign merchants mainly of the Raguzians we have also after the death of Serbian Emperor Stefan Dushan. For this reason, Raguzan's diplomacy was careful to reaffirm its immediate privileges (for free trade), which were previously guaranteed by the ruling rulers of the Nemanjid dynasty. To this end, the Grand Council of Ragusa appointed the delegation to Prizren where he met with the emperor of Serbia, the Nemanjid Uroshin V. Meanwhile, Urosev V Dragoslav's representative handed over to the missionaries of Ragusa Marin de Bona, Giovani de Gondola and Giue de Cerva five diplomas signed by Uroshi V in Ribnik (near Prizren) and in Prizren, with which he confirmed the free 
trade of Raguzan government free of charge with the city of Prizren and the entire nemanjida empire. ${ }^{73}$ One of these diplomas issued on April 24, 1357 guarantees free trade in general, while a gold diploma issued on April 25, 1357 reconfirms the privileges guaranteed by Emperor Dushan in $1349 .^{74}$

At the time of the reports of aggravated reports after 1358 between Ragusa and the Nemanjid state and especially the events of 1361, the commercial relations between Ragusa and the city of Prizren were directly struck. In addition to this factor, the other conditions created in Kosovo, in particular after the increasing pressure of the Ottomans during the last thirty years of the 20th century, reduced the trade relations between them. XIV. Another factor that greatly affected the weakening of relations between Ragusa and Prizren was the occupation of the port of Saint Shirgjit (1399) from the Venetian Republic, which now prohibits Raguzan from transporting the Zeta road towards Prizren, which naturally brought about consequences nnfavorable for the further advancement of the connections between Ragusa and Prizren. ${ }^{75}$ 


\section{BIBLIOGRAFI}

ČERŠKOV, E. - Romans in Kosovo, and the municipium D.D. of Soçanica, Pristina, 1973.

ČREMOŚNIK, G. - "Dubrovački konzulati u srbiji do Dušanovog vremena", Glasnik Zemaljskog Muzeja, Sarajevo, 1929/VLI-2.

ČREMOŠNIK, G. - "Kancelarski i notarski spisi, 1278-1301”, (Frontes Rerum slavorum Meridionalium) serija treča, sv. I. Istorijski Spomenici Dubrovačkog Arhiva, Belgrad, 1932.

DACI, S. - "Some economic data on Kosovo during the Middle Ages", Bulletin of the Faculty of Philosophy XIII/1993, Pristina, 1993.

DRANÇOLLI, J., - "Kosovo's roads during the Middle Ages”, Vjetai, Arhiv of XXIII, Pristina, 1987.

Državni Arhiv u Dubrovniku - Debita Notariae XXXVI, Box, 4.

Državni Arhiv u Dubrovniku - Debita Notariae, XXXVI, Box 12.

Državni Arhiv u Dubrovniku - Diversa Cancellariae XV, Box 13.

Državni Arhiv u Dubrovniku - Diversa Cancellariae XXV, Box, 14.

Državni Arhiv u Dubrovniku - Testamenta de Notaria X, Box 3.

Državni Arhiv u Dubrovniku - Testamenta de Notariae I, Box,11

Državni Arhiv u Dubrovniku Preacepta Rectoris I, Box, 2.

Državni Arhiv u Dubrovniku, Preacepta Rectoris I, Box 2.

GELCICH, J. - Monumenta Ragusina, (Libri reformationum), tomus. V. (1301-1336), Zagrabiae 1897.

GELCICH, J. - Monumenta Ragusina, II, Zagrabiae, 1882.

JERIÇEK, K. - Spomenici srpski, “Spomenik” SKA, Beograsd, 1892/XL.

JIREČEK, K. - Istorija Srba I, Beograd, 1952.

JIREČEK, K. - Istorija Srba II, 173.

JORJO. T.h, - Pisma i ypustva Dubrovačke Republike knjiga I (Litterae et Commissiones Ragusiana), Zbornik za IKJ treče odelenje, knj. IV, Belgrad 1935.

MANKEN, I. - "Dubrovački patricijat u XIV veku, Posebna izsdanja, SANU, Odeljenje društvenih nauka, Belgrad, 1960/CCCXL-36.

MILLUTINOVIČ, B. - “Zaduženja prizrenskih trgovac kod dubrovčana 1355-13269 godine”, Vjetari / XIV-XV, Pristina, 1982.

Muhadri, Bedri - "Economic development of Prizren during XIII- XV Centry", European Journal of Social Sciences Studies, Volume 2, Issue 3, 2017.

MUHAMET, M. - "Relations of Kotor in Albanian lands during the century. XIV - XV", (unpublished master University of Pristina, 1996).

RIZAJ, R. - Ksovo over the centuries XV, XVI dhe XVII, Rilindja, Pristina, 1982.

SHKODRA, Z. - Albanians guilds (cent. XV-XX), Tirana, 1973.

SHUFLLY, M. - Serbs and Albanians, Pristina, 1978. 
ŠKRIVANIČ, G. - Mreža puteva prema Cvetostefanskoj (1311-1318), Gračaničkoj (1321), Dečanskoj (1330) i Cvetoarhanđelovskoj Povelji (1348-1352)", Istoriski $\begin{array}{llllll}\text { Časopis } & k n i j g a & V & 1954-1955, & \text { Belgrade, } & 1955 .\end{array}$ Selected sources for the history of Albania, II, cent. VIII-XV, Tirana, 1962.

STATOVCI, D. - Historical development of handicrafts and its contemporary relevance to the economic and social structure of the Kosovo SAP, Pristina, 1982.

STOJANOVIČ, L. - Stare ssrpske povelje i pisma, knj. I, prvi deo, Zbornik za IJK Srpske Narode, knj. XIX, Belgrad, 1929.

VINAVER, V. - "Ragusa traders in Kosovo and Metohija", "Progress", Pristina, 1961 / 3. 


\section{NOTES}

${ }^{1}$ Many Albanians and Foreign Scholars have written about the road "Via de Zente" like: Jahja Drançolli, "Kosovo's roads during the Middle Ages", Yearbook, XXIII, Pristina, 1987, 55-65; Gavro, "Skrivanic, Road network to Cvetostefanska (1311-1318), Gračaničkoj (1321), Dečanskoj (1330) i Cvetoarhanđelovskoj Povelji (1348-1352)", Istoriski Časopis knijga V 1954-1955, Belgrade, 1955, 387 397.

2 Selected Sources for the History of Albania, II, c. VIII-XV, Tirana, 1962, 143- 155.

${ }^{3}$ Selim Daci, "Some economic data on Kosovo during the Middle Ages", Bulletin of the Faculty of Philosophy XIII/1993, Pristina, 1993, p. 111.

${ }^{4}$ Jahja Drançolli, Raguzans in Kosovo (From the end of XIII century until 1455), Pristina, 1986, 169.

${ }^{5}$ Ibid

${ }^{6}$ Ibid.

${ }^{7}$ Daci, "Some economic data on Kosovo", p. 113.

8 Ibid., 114.

${ }^{9}$ Ibid.

${ }^{10}$ Državni Arhiv u Dubrovniku, (further DAD)., Diversa Cancellariae XV, Box 14, fol. 136; (Documents until 1417 are stored in the fund series: Reformations incluing, testamenta Notariae, Preacepta Rectoris, Diversa Cancellariae);

${ }^{11}$ Daci, "Some economic data", 116.

12 Ibid., 116.

${ }^{13}$ Muhamet mala, "Relations of Kotor in Albanian lands during the century. XIV - XV", (unpublished master's thesis University of Pristina, 1996), 151

14 Milan Shuflly, Serbs and albanians, Pristina, 1978, f. 50; K. Jireček, Istorija Srba I, Beograd, 1952, 286.

${ }^{15}$ Daci, "Some economic data", 117

${ }^{16}$ Drançolli, Raguzans in Kosovo, 171

17 Skender Rizaj, Kosovo over the centuries XV, XVI dhe XVII, Rilindja, Pristina, 1982, 93.

${ }^{18}$ Drançolli, Raguzans in Kosovo, 116.

${ }^{19}$ Selected sources, 149; Milan Shufflay, Serbs and Albanians, 50

${ }^{20}$ Ibid., 50

${ }^{21}$ Drançolli, Raguzans in Kosovo, 167

22 Ibid.

${ }^{23}$ Ibid.

${ }^{24}$ Ibid.

${ }^{25}$ Ibid.

${ }^{26}$ Ibid.,168.

${ }^{27}$ Ibid.

28 Ibid.

${ }^{29}$ Ibid.

30 Emil Čerškov, The Romans in Kosovo, and the municipium D.D. of Soçanica, Pristina, 1973, 52; Drita Statovci, Historical development of handicrafts and its contemporary relevance to the economic and social structure of the Kosovo SAP, Pristina, 1982, 55.

${ }^{31}$ Zija Shkodra, Albanian guilds (cent. XV - XX), Tirana, 1973, 60; Shufflay, Serbs and Albanians, 51.

32 Selected Sources, 145.

${ }^{33}$ Drançolli, Raguzans in Kosovo, 196.

${ }^{34}$ Shkodra, Albanian guilds, 60.

${ }^{35}$ Drançolli, Raguzans in Kosovo, 203. 
${ }^{36}$ Rizaj, Kosovo over the centuries, 115.

37 Ibid, 50.

38 Vuk Vinaver, "Ragusa traders in Kosovo", "Përparimi", Prishtinë, 1961 / 3, 149.

39 Jireček, Istorija Srba II, 173.

${ }^{40}$ Selim Daci, "Economic activity of Kosovo cities during XI-XV centuries", (doctoral thesis, unpublished Univetrsity of Pristina, 1985), 211.

${ }^{41}$ Jireček, Istorija Srba II, 173, 425.

${ }^{42}$ Drançolli, Raguzans in Kosovo, 199-201.

${ }^{43}$ Ibid., 160.

${ }^{44}$ Ibid., 163.

${ }^{45}$ For the activity of the Ragusa consulate in Prizren more widely J. Drançolli, Raguzanët në Kosovë (Prej fundit të shek. XIII deri në vitin 1455), Pristinë, 1986, 45-59; G. Čremośnik, “Dubrovački konzulati u srbiji do Dušanovog vremena", Glasnik Zemaljskog Muzeja, Sarajevo, 1929/VLI-2, f. 82-94; B. Muhadri, "Economic development of Prizren during XIII- XV Centry", European Journal of Social Sciences Studies, Volume 2, Issue 3, 2017, 132-140.

${ }^{46}$ Daci, "Economic activity of Kosovo cities", 241.

47 Drançolli, "Raguzans in Kosovo", 186.

48 Ibid., 86.

${ }^{49}$ Ibid.

50 Ibid., 189.

${ }^{51}$ DAD, Preacepta Rectoris I, Box, 2, fol. 100a. "Die V. exeunte mensis octuburis [1299]. Ego quidem Bogsdanus de Rasdoslauo sde Prisreno confiteor, quod super me et super omnia mea bona usque ad primum festum nativitatis Domini debeo dare Laurencio de Sauina yperperos CCCC"; Gregor Čremošnik, "Kancelarski i notarski spisi, 1278-1301", (Frontes Rerum slavorum Meridionalium) serija treča,, sv. I. Istorijski Spomenici Dubrovačkog Arhiva, Belgrad, 1932, 180.

${ }^{52}$ DAD, Preacepta Rectoris II, fol. 126a ; “Die V. intr. Mens. iunii [1300]. Ego quidem Crabeç, gener de Crana de Prisreno, confiteor, quod super me et omnia mea bona usque ad quatuor mense proxime veturos debeo dare Alegreto, cugnato Mauresse, yperperos CC"; Čremosnik, "Kancelarski i notarski", 180.

${ }^{53}$ DAD, Precepta rectoris I, Box, 2, fol. 160 "Die XXXIII. Intr. Mens. masdii [1301]. Ego quidem Rade Dobreloviç de Prisreno confiteor, quosd super me et super omina mea bona usque ad duos mense proxime venturos debeo dare Marco Lucari de Fusco yperperos XVII; Čremosnik, "Kancelarski i notarski..." 180.

${ }^{54}$ Drançolli, Raguzans in Kosovo, 190.

55 Ibid., 190.

56Ibid., 183.

${ }^{57}$ Irmgrad Manken, "Dubrovački patricijat u XIV veku, Posebna izsdanja, SANU, Odeljenje društvenih nauka, Belgrad, 1960/CCCXL-36, f. 123, 124.

58 Branislav. Millutinovič, "Zaduženja prizrenskih trgovac kod dubrovčana 1355-13269 godine”, Vjetari / XIV-XV, Pristina, 1982, 50.

${ }^{59} \mathrm{Ibid}, 50$.

${ }^{60}$ DAD, Debita Notariae XXXVI, Box, 4, speak 67, ( on 25.V. 1359)

${ }^{61}$ DAD, Debita Notariae XXXVI, Box, 4, speak 81.

${ }^{62}$ DAD, Debita Notariae XXXVI, Box, 4, speak. 102, 109, 135v

${ }^{63}$ Drançoli, Raguzans in Kosovo, 193

${ }^{64}$ Ibid., 189.

${ }^{65}$ DAD, Testamenta Notariae X, Box, 11 fol. 144; Debita Notariae XXXVI, Box, 12, speak 76v; XXXI, speak 25; Jorjo. Tadih, Pisma i ypustva Dubrovačke Republike knjiga I (Litterae etCommissiones Ragusiana), Zbornik za IKJ, treče odelenje, knj. IV, Belgrad 1935, 33-34. 
${ }^{66}$ DAD, Preacepta Recepta I, Box, 2, fol. 7a; Čremošnik, “Kancelarski i notarski spisi..., (1278-1301) "Die ultimo mensis iulli [1299]. Dimitrus Miroseviç Deanam de Prisreno, ancillam presentem et consentientem vendidit diffinite ad mortem. Vladimiro de Grupsa pro yperperis viginti, quos recipt ab eo, ut ipse Vladsdimirus de dicta Deana, ancilla sua, in perpetuum velle suum facita" (më 321.VII. 1299).

${ }^{67}$ Josephus Gelcich, Monumenta Ragusina, (Libri reformationum), tomus. V. (1301-1336), Zagrabiae 1897, f. 326.

${ }^{6}$ DAD, Testamenta de Notariae X, Box, 3, 40-41; Drançolli, Raguzanët në Kosovë, 110

${ }^{69}$ Konstandin Jeriçek, Spomenici srpski, "Spomenik" SKA, Beograsd, 1892/XL, 100.

70Ibid.

${ }^{71}$ DAD, Diversa Cancellariae XXV, Box 13, fol. 46; Jeriçek, Spomenici srpski, 100; Drançolli, Raguzans in Kosovo, 123

72 Josephus, Gelcich, Monumenta Ragusina, II, Zagrabiae, 1882, 24.

${ }^{73}$ Drançolli, Raguzans in Kosovo, 116

${ }^{74}$ Ljube Stojanovič, Stare ssrpske povelje i pisma, knj. I, prvi deo, Zbornik za IJK Srpske Narode, knj. XIX, Belgrad, 1929, 94-97.

${ }^{75} \mathrm{Ibid}, 119$. 